\title{
The Systemic Global Crisis: A Long Cycles Approach with a Political - Economic Perspective
}

\author{
MARIO EDUARDO FIRMENICH \\ Universidad Rovira I Virgili, Facultad de Economía y Empresa, Avda. Universitat, 1, 43204 Reus \\ (Barcelona), Spain. E-mail: marioeduardo.firmenich@urv.cat
}

\begin{abstract}
International financial crisis reflects a systemic global crisis. The revolution of ICT have given infrastructural basis to global markets, especially the financial market, which was backed up by institutional deregulation. However it has been generated a global system with the hegemony of the car-petroleum tandem and with liquidity generated by the free mobility of capitals without institutions which regulate it. Worldwide order established in the postwar period is not at all functional to the globalization sustained in the ICT. To solve peacefully the global crisis it is required a political decision to set up a New Sustainable International Order.
\end{abstract}

Keywords: Crisis, Globalization, International Monetary System, Kondratieff.

\section{La crisis sistémica global: Una aproximación desde los ciclos largos con una perspectiva político - económica}

\begin{abstract}
RESUMEN
La crisis financiera internacional refleja una crisis global sistémica. La revolución de las TIC dio base infraestructural a los mercados globales, especialmente el financiero, lo que fue apoyado por la desregulación institucional. Pero se generó un sistema global con la hegemonía del tándem “automotor-petróleo" y con una liquidez generada por la libre movilidad de capitales, sin las instituciones que lo regulen. El orden mundial establecido en la posguerra no es funcional para la globalización sustentada en el predominio de las TIC. Para resolver pacíficamente la crisis global es necesaria la decisión política de crear un Nuevo Orden Internacional Sustentable.
\end{abstract}

Palabras clave: Crisis, globalización, sistema monetario internacional, Kondratieff.

JEL Classification: F53, E32, 033

Artículo disponible en versión electrónica en la página www.revista-eea.net, ref. ə-35305 


\section{THE IRRUPTION OF A CRISIS WITH A CONFUSED DIAGNOSIS}

After the outbreak of the crisis in 2008, between late 2008 and the first half of 2009, hundreds of billions of dollars and euros were delivered to rescue the financial system in the United States (US) and the European Union (EU) ${ }^{1}$. But despite optimistic expressions it did not solve the problem; the subsequent fall of stock markets around the world showed so. ${ }^{2}$

Many people began to suspect in 2009 that the principles of neoliberalism were responsible for the situation; in response, they reread KEYNES (1936) and the New Deal of Roosevelt, ignoring structural changes happened during more than 7 decades between those 30s of XX century and the first decade of the XXI century.

In April 2009, the Second Summit of the G20 in London tried to solve the crisis with a multilateral pseudo-Keynesianism quoting a problem of "weakness" of global institutions and ecosystem crisis as an inseparable part of the economic crisis. There was an international agreement about billionaires national fiscal stimulus and a policy of "cheap money". But, considering the problem of "strengthening international institutions", the G20 (2009) has understood it more as a quantitative problem than as a qualitative problem; his proposals were give more money to the International Monetary Fund (IMF) together with the presence of the Financial Stability Board instead of understanding the structural crisis of postwar International Monetary System (IMS).

Intentions regarding environmental issues were short-lived. The pledges made by United Nations Conference on Climate Change in December 2009 in Copenhagen to curb global warming became an increase in the rate of emission of greenhouse gases, which in 2011 reached a new record (WORLD METEOROLOGICAL ORGANIZATION, 2012) and a report, prepared at the request of the WORLD BANK (WB) (2012), alert that if the current pattern of production and consumption is not changed humanity will suffer the consequence of global climate disasters in this century.

\footnotetext{
${ }^{1}$ In early October 2008 in USA passed the law on the plan to nationalize banks' bad loans in the amount of 700,000 million. Immediately after European governments launched publicly billionaire bailouts to provide liquidity and prevent the collapse of its major banks, Germany announced a package of more than 500,000 million euros, Netherlands fixed 200,000 million euros, France approved a plan for 360,000 million euros, Austria and Spain announced each a maximum of 100,000 million euros, the British plan was 380 billion euros, Portugal announced 20,000 million and the Bank of Italy made available to banks up to 40,000 million euros. See El Universo (2008).

${ }^{2}$ In The New York Times (2008), it is posted an interactive chart to compare with previous crisis and concludes that it is the worst decline in 80 years.
} 
In May 2010, the EU decided another economic policy which was exactly the opposite. Since the focus of the measures adopted in April 2009 by the G20 was apparently Keynesian, subsequent recurrence of the crisis on the stock markets and its consequence on the public debt crisis in the EU's countries is tried be resolved with a return to neoliberal adjustment.

\section{THE GENERAL SYSTEMS THEORY AND POLITICAL - ECONOMIC SYSTEMS}

BERTALANFFY (1968) defines dynamic systems as open and adaptive systems that evolves with an intentionality and with a feedback of the information obtained in its evolution. Open systems exchange materials with their environment and have internal processes that constitute and degrade their material components. Open systems never reach a static equilibrium, but rather approach an independent state of time called "steady state": some variables are in "balance" due to a continuous flow and degradation of materials and energy.

Systems are not a sum of parts, but a complex organization of parts.

Living organisms are open systems. Various authors have studied social systems as living systems (VOLTES BOU, 1980). According Mc CLELLAND (1958), the systems of social organization that lead the historical process are dynamic, open and adaptive systems.

But the "pure economic system" is an ahistorical abstraction. The only human reality like an economic system without political system are Paleolithic tribes of hunter - gatherers in prehistory ${ }^{3}$. The evidence in the history of mankind can sustain the thesis that the areas of economics and politics are interdependent realities, what means seeing economy and policy as subsystems of a same political - economic system which evolves with a political intention.

According FIRMENICH (2015), the Political - Economic System contains a political subsystem and an economic subsystem that share the Social Structure at its intersection. The political subsystem contains two subsets of elements: the Governmental Apparatus and Social Structure. The economic subsystem also contains two subsets of elements: the Productive Apparatus and the Social Structure. Both subsystems and the three subsets of elements lack selfreproduction and autonomous equilibria outside the system as a whole.

When the economic subsystem that produces surpluses is mathematically formalized into monetary units, there are more endogenous variables than equations, situation posed by SRAFFA (1960) and deepened by FIRMENICH

\footnotetext{
${ }^{3}$ HARRIS, M. (1991) argues that, in Paleolithic tribes, there is the phenomenon of leadership, but it has a very different form of the state as politically organized society, where the ruling elites have the power to compel subordinates to pay taxes, provide services and comply with the law.
} 
(2015). Since the system of equations formalizes multisectoral market exchanges, the need for exogenous decisions to determine the system means that the solution of the system is outside the academic field of pure economics. This is a formalization of evidence that in the systemic realities of the history, prices are not independent of the income distribution and the distribution of the economic surplus is not independent of the political and institutional framework.

There is a great weakness of current economics which is the assumption that there is an autonomous general equilibrium of "pure economy". This would mean that economy is an independent system which is self-regulating and selfreplicating. But the historical evidence and the systems general theory say that is wrong.

The system of equations, with physical quantities as known data and prices and distributive variables as unknowns, needs the exogenous determination of the value of as many variables as the degrees of freedom the system has.

In an economy capable of producing cumulative surpluses as wealth, no general equilibrium of market prices is autonomously possible. The determination of the economic subsystem requires the institutional organization of the political subsystem with sufficient power to impose the exogenous values of the distributive variables of the income. NORTH (1981, p. 21) says:

“... a state is an organization with a comparative advantage in violence, extending over geographic area whose boundaries are determined by its power to tax constituents. The essence of property rights is the right to exclude, and an organization which has a comparative advantage in violence is in the position to specify and enforce property rights. In contrast to the theories frequently advanced in the literature of political science, sociology, and anthropology, here the key to understanding the state involves the potential use of violence to gain control over resources."

The state authority has the capacity for armed coercion to levy taxes on a part of the surplus production, in order to finance its own costs as a state organization and to finance public works. But, in addition, the state has the power to politically impose determined values on variables and parameters of income distribution, defining the degrees of freedom of the system. This makes it possible to determine prices through the market.

Historical evidence shows that all Political - Economic Systems have evolved dynamically with imbalances of inflationary or deflationary pressures, shortages and famines or crises of overproduction, booms or depressions, besides the imbalances that generate or that are generated by wars and revolutions. However, historical evidence shows that systems do not necessarily evolve with dynamics of explosive imbalances because of this. The dynamics of the system is structurally unbalanced but disequilibrium is limited by the political - institutional decisions of the state. 
Any determination of a stable dynamic equilibrium of the economic subsystem depends on the existence of services of an institutional power, which imposes social compliance to an economic surplus' distribution determined politically. If the distribution of surplus is modified, it also changes the social use of surplus modifying both the pattern of consumption as the investment; therefore dynamics of system is changed also.

Sometimes even the political - military power of the state is unable to control imbalances. This is witnessed by civil wars, political and social revolutions, invasions of or from other systems and even the catastrophic disappearance of many Political -Economic Systems.

History shows that the political organization of the state, as an institution capable of ordering the allocation and use of surpluses, in similar economic situations, has had alternative political solutions with different institutions that have given rise to different social, economic and political dynamics.

As HOFF \& STIGLITZ (2001, p. 389) say:

"We know that development is possible, but not inevitable. ( ... ) Development is no longer seen primarily as a process of capital accumulation but rather as a process of organizational change."

According to how the political - institutional subsystem is organized and according to its organizational change process, the economic dynamics will be efficient or inefficient, more evolved or more backward, more cooperative or more conflictive.

Economic efficiency depends on the political subsystem's efficiency and vice versa. Any institutional model could, in theory, ensure the economic equilibrium on the condition that obtains the consent of the socioeconomic agents in the allocation and use of the surplus. From the standpoint of economic efficiency, the systemic costs will be minimal when the consensus is maximized. When the agreement is void, the costs are unsustainable and the system explodes.

There is a feedback on the development of system dynamics. System efficiency is the result of social sustainability, economic sustainability, environmental sustainability and political sustainability, while feedback is a cause of them.

\section{THE GLOBAL POLITICAL - ECONOMIC SYSTEM}

Throughout the secular trend of global integration communications have become globalized. But the qualitative leap with telematics technology is that they have become a global network of interactive multimedia communications in real time.

It has set up a global system, with globalized financial market, with globalized goods and services markets, and, although with severe restrictions on 
the mobility of workers, also with a globalized labor market. The global system is not a sum of national systems. The components of a global system, (it is to say, the national economies as subsystems) have no independent existence, have no independent life outside the system.

But, in spite new technologies and deregulation modified the global economic subsystem, it does not happened any organizational change in global political subsystem.

Globalization has reduced the sovereignty of national states. This is because the telematics technology applied to the management of the international financial system together with the multiplication of the international mobility of capital, destroyed the monetary sovereignty of the Nation - States. The Nation - State has lost or is in the process of losing its sovereignty in four well - defined areas: 1) monetary sovereignty, 2) sovereignty over the means of telecommunication, 3) sovereignty over the human rights of its "subjects," 4) ecological sovereignty over its natural resources. However, it did not be builded still a new political institution which be the new sovereign subject on those areas.

Industrial production by multinational companies that take advantage of each comparative and / or competitive advantage has generated the global workshop. Small plants scattered around the planet produce parts and components that are then assembled in small plants installed anywhere in the world. This transformation is associated with a flow of capital linked to social dumping.

The global workshop relativizes the concept of "domestic industry" due to the increasing proportion of imported components, which are often transactions within the same economic group. This facilitates under -invoicing or overinvoicing to cover up transfer of benefits from one country to another. Thus the new productive structure facilitates a globalization of tax evasion.

The global labor market is subject to globalization biased by state regulations. Globalization of the labor demand is allowed due to the relocation of industries to countries with lower labor costs. But there are severe legal restrictions on workers' movements from low - wage countries to those with high wages. The globalization of the labor market does not allow excess demand to fit as neoclassical economic theory says.

The dynamics of the economic subsystem have their own impulses derived from the technologies used and the delayed effects of public and private decisions of the past. Since the industrial revolution of the eighteenth century, the growing integration of the world market driven by technological revolutions has evidenced a cyclical dynamics of long duration in the globalization of the economic subsystem.

These long time cycles, known as Kondratieff cycles (KONDRATIEFF, 
1925) ${ }^{4}$ last an average of about 54 - 56 years, with a phase called "upward long wave" and another one called "downward long wave", which have approximately the same duration each, or about 27 to 28 years. Other economists have studied important subjects of the Kondratieff cycles, as SCHUMPETER $(1939)^{5}$, LEE $(1955)^{6}$ or TAYLOR (1985) ${ }^{7}$.

But the development of the upward long wave Kondratieff cycle depends not only on the new technology, but also of new institutional regulation of finance and trade as well as regulations of the new social, political and military order.

The lag between the onset of the economic expansion of the new technology and building new institutions for managing the global market's new cycle is something reiterated in Kondratieff cycles.

It is important to clarify that dynamics of political - economic system does not imply any technological predetermination. The expansion of production and consumption within the possibilities and constraints of a technology can support many forms of institutional structure, which are not determined but only conditioned by technological restrictions. Thus, a long time telematic cycle can be both a qualitative change favorable to the quality of life of human beings across the globe, as the cause of the destruction of humanity in a nuclear "Star Wars", or a new ecological balance not suitable for our survival as specie.

There is no inexorable future. The future depends on the socio - political evolution, with the constraints of technology, human and natural resources ${ }^{8}$. Technology with human and natural resources defines the restriction called Production Possibilities Frontier. But policy is and it will be the management of the degrees of freedom that has the economic subsystem; this way, it is decided how the economic surpluses are reinvested. According to the allocation done of these surpluses, it will vary the system's future development. Reinvest surpluses in researching new technologies will not give the same kind of historical

\footnotetext{
${ }^{4}$ Nicolai Dimitrievich Kondratieff was Kerensky government minister and led the Economic Research Institute of Moscow from 1920. Because the heterodoxy of his theory of long cycles was jailed in 1930, during the time of Stalin, and deported to Siberia. He exhibited his first ideas about the long economic cycle in 1922 at the Third Congress of the Third International.

${ }^{5}$ In his study trying to relate the cycles short, medium and long, Schumpeter called the long cycle of the industrial revolution to the first Kondratieff, and the second as the Kondratieff rail.

${ }^{6}$ Lee explains the Great Depression of the decade of the 30s in terms of the downward phase of the third Kondratieff cycle, followed by an upward trend from the 40s that could be interpreted as the beginning of fourth Kondratieff.

${ }^{7}$ Taylor summarizes that in the 80s, almost all authors agreed that there had been four Kondratieff cycles since the industrial revolution, but that there is no coincidence about the causes of the cycle.

${ }^{8}$ See GIULIANO (2008) for a discussion about the relationship between the theoretical conception of technology and the development of life in a society.
} 
development than if they are reinvested in greater consumerism with existing technologies or if they are used to fund armies in order to do wars of conquest.

\section{AN INTERPRETATION OF THE POSTWAR WORLD CYCLE AS THE "KONDRATIEFF AUTOMOTIVE"}

The global economic development after the Second World War (WW II) can be seen as the fourth Kondratieff cycle. This would have started around 1940 in the US (and, perhaps, a little later in the Union of Soviet Socialist Republics), and immediately after the WW II in the rest of the industrialized capitalist countries.

The long cycle after the WW II is dominated by technology corresponding to the metal industry of durable goods, taking the automobile industry with combustion engine as the primary production of final goods for mass consumption, and, as a necessary complement, the energy production based on cheap oil.

In July 1944, in Bretton Woods, representatives of 44 countries had agreed to the institutional basis of the new international financial system, based on the pattern convertible gold (dollar standard), for the new IMS. There was created the IMF and the WB. In February 1945, Churchill, Roosevelt and Stalin met at the Yalta Conference. There they agreed to a peace for 50 years for the world that would be structured after the war. The June 26, 1945, in San Francisco, is signed the United Nations (UN) charter. A new international institution replaced the League of Nations, which was established during the third Kondratieff, with the Treaty of Versailles in 1919.

For the global system, we can consider that, in 1944 - 1945, begins long wave upward when the new international order is institutionalized. Just then the systemic political and economic organization is structured, this organization is functional to economic growth under the hegemony of the US as the economy most representative of the technology that streamlines the cycle "automobile petroleum."

The upward long wave lasts just over 25 - 26 years. We can consider that in 1970 - 1971 starts the downward long wave. The crisis is installed in the late '60s in the worldwide financial system. But the milestone is when President Nixon unilaterally declared the no convertibility of the dollar into gold in 1971 (PRELOOKER, 1996) ${ }^{9}$.

On 24 April 1972 the European Economic Community countries established a commitment about exchange rates between their currencies, defined by a system of fixed exchange rates with a band for adjustable parities. But in the context of

\footnotetext{
${ }^{9}$ Prelooker believes that on 15 August 1971, when President Nixon declared unilaterally broken the Bretton Woods Agreements, about the dollar's convertibility into gold, starts "officially" long wave downward, corresponding to Kondratieff IV.
} 
prevailing international destabilization, (in February 1973 the dollar had suffered a further devaluation), the European experience is short-lived, as the March 19, 1973 disappear fluctuation bands against the dollar. So completely disappears Bretton Woods system, established on the principle of the dollar as key currency convertible and fixed exchange rates.

When Organization of Petroleum Exporting Countries puts his finger on the wound of the energy source in 1973 (after the Israeli occupation of Arab territories in the 1967 war and after the devaluation of the dollar in April 1972 and February 1973), the multiplication of oil prices unbalances definitely the global financial system, established for the long cycle "automobile-petroleum."

But this is only the financial aspect of the crisis of the storage capacity and expandability, for the production paradigm that characterizes the fourth Kondratieff. The integrated phenomenon, reflecting the financial crisis and the crisis of production as two sides of the same coin, was named "stagflation". The recurrent oil shocks (the Iranian revolution in 1979 returns to affect the world oil market) -beyond the episodic casuistic nature each of them- point to the existence of the crisis in one of the central aspects of any Kondratieff cycle, ie: the kind of energy needed for the dominant technology and how to supply its generation. Moreover, the growing confrontation among the world's major automakers, particularly American companies against Japanese companies over the '80s, by overlapping markets reveals the crisis in the expansion of the industry producing mass consumption goods that characterizes this cycle.

Then it begins the accumulation of large amounts of capital; they can not find enough profitable forms of productive reinvestment, which will create a new circuit purely financial. However, this financial accumulation is not a "neutral waiting for a new opportunity" to invest, but it becomes the cause of the deepening crisis of the worldwide system (which had entered into its decline of the long wave downward) while it generates the accumulation of capital for the expansion of the next cycle.

An expression of this phenomenon is also the rise of the external debt crisis of the Third World countries (with the outbreak of the Mexican foreign debt in 1982) and the simultaneous impoverishment of their peoples in the early '80s. This was generated by financial circulation of capital's surplus, because there are no opportunities for industry profitable reinvestment in the cycle which expires. This movement generates financial crisis of productive underinvestment, with the effect of the impoverishment of those who do not receive these investments that create new jobs, but they pay interest on the movement of financial capital's surplus.

The "Kondratieff automotive" downward long wave lasts just over 25 - 27 years, reaching the second half of the decade of the '90s. This also explains the 
prominence of the depth and duration of the crisis (recessions), regarding booms along the short cycles, during the last decades of the twentieth century.

\section{THE HYPOTHESIS OF A “KONDRATIEFF TELEMATIC CYCLE”}

We hold as plausible the hypothesis we have experienced the end of the fourth cycle and the beginning of fifth Kondratieff cycle in the mid-90s of XX century. The new Technologies of Information and Communication (ICT) lead us to call this new cycle as the "telematic Kondratieff cycle". With all of precautions about the imprecision of economic prediction, hypothetically this cycle could last for about 54 - 56 years, from 1995 / 1996 until 2050 / 2051. ${ }^{10}$

Under this hypothesis, we can say that the crisis of the downward long wave of "automobile - petroleum" Kondratieff cycle began to be overcome by economic expansion resulting from the profitable operation of spacecraft propelled by solid fuels and telecommunications satellites connected with personal computers, structured as a global network "on line" through the fiber optic telephone system and mobile telephony. ${ }^{11}$

As evidenced in previous cycles, there may be a lag between the start of the cycle in different central countries of the global system. Thus it is likely that the new upward long wave started in the US in the mid-'90, before than in the rest of the great industrial centers. Describing the US Economy of this time,

${ }^{10}$ It is known that the word "cycle" in economic science doesn't have the rigorous meaning it can have on the physical and natural sciences. This is because, in economics, fluctuations that occur regularly booms, crisis, contraction and recovery are called "cycle" but they are fluctuations without a precise frequency and, especially in macro cycles, variable time is not considered a cause of such fluctuations. In this sense, it is not possible to do rigorously chronological predictions based on knowledge of past economic fluctuations. Furthermore, in the case of longterm cycles, we have no satisfactory explanation of why some processes with qualitative differences among themselves, given the changing historical circumstances over more than two centuries, have shown approximately the same period of about 55-56 years average life time. This regularity allows us to have a working hypothesis about the future, but this does not authorize us to make an accurate prediction.

${ }^{11}$ Technological revolution generates new industries of final goods and new energy technologies; the old industries do not disappear but are transformed by other innovations. The railway with steam engine and coal-fired was displaced by the car with explosion engine and petroleum fuel; then the railway was modernized with electric diesel engines and fully electric motors. At the present time, automotive - oil industry, in addition to slowing down its expansion, has led humanity to the risks of climate change and global warming, generating concern for sustainable development. Thus, new telematics technologies are accompanied by other innovations in the old industries and their energy technologies. For a discussion about relation between technological innovation in renewable energy and sustainable development, taking in account that energy based in fossil fuels are responsible for the global warming and climate change, see PIRES MANS0, J. R. \& BASHIRI BEHMIRI. N. (2013) 
LUTTWAK (1996) emphasizes the impressive progress of computer companies versus the old "titans" of the industrial age.

We accept that, in the mid-'90, ICT became the most dynamic of technologies considering the economic profitability, and this is because it is the one that opens new markets with generation of technological quasi - rents displacing technologies associated with cycle of the tandem "automobile - petroleum". A clear example of this is that in the late twentieth century the richest man in the world ceased to be an oil tycoon. Even clearer, the "flagship" of the global automotive industry sank: General Motors must file for bankruptcy in 2009.

However, the economic expansion based on a technological revolution does not protect the system from possible financial crises. In fact, profitability of technological structural change's key industries was a new opportunity for a speculative stock market bubble, the bubble of "dot-com", which erupted in 2001 and it is at the origin of the subsequent global housing bubble (HERRING, \& WACHTER, 2002), (HELBLING \& TERRONE, 2003).

Just as there is some convergence of views about the fourth Kondratieff began in the US around 1940, institutional settings, both economic and political, for the imposition of this cycle only ended in 1944 / 1945, when it was completed WW II.

During the third Kondratieff cycle, economic expansion of new technology began in the late nineteenth century, following the "second industrial revolution", but the global new institutions are not created until the Treaty of Versailles, after the First World War.

Something similar to what happened during the third Kondratieff is happening right now, as it seems clear that in 1996 the US economy had obvious signs of the beginning of "telematic cycle", while it is public knowledge that the world does not have, until today, more than twenty years later, a new institutional framework of globalization (both the economic as political sides) functional to economic development reoriented by the technological revolution.

The fifth Kondratieff exhibits, with relative clarity, its energetic and technological traits, but it has not yet defined its overall institutional profile. The prominence during the last decades of neoliberalism and the Washington Consensus (WILLIAMSON, ed., 1990) had no global institutional status or universal political consensus or realistic prospect of establishing a new world order that has not founded in fact.

\section{THE SYSTEMIC NATURE OF THE CURRENT GLOBAL CRISIS}

There is an incongruity in the current state of financial globalization. The world monetary order continues to be based on the dollar pattern, as an agonically 
hegemonic currency, along with the institutions of the world order established in Bretton Woods: the IMF and the WB.

But the dollar is no longer the currency convertible into gold at the fixed parity of \$ 35 an ounce. In addition, the euro has emerged, stronger than the German mark, and the Chinese yuan is recognized as an international currency. The preeminence of the dollar no longer depends on an institutionalized global consensus, but on the rivalry between the major currencies, arbitrated by speculative capitals more powerful than all the central banks combined.

This system has been defined as the abandonment of the international monetary order of the key currency, associated with the principle of convertibility, which is replaced by global financial competition. Acording AGLIETTA (1987, p. 141 - 142):

"The global financial competition can not drive more than the rivalry of currencies, ... an asymmetric rivalry, since the size of the markets that use the dollar assure its preponderance... But the preponderance of a currency in financial competition is not a monetary principle"12.

The equilibrium of an IMS such as that inherited from the postwar period demands the hegemony of a key currency, which is the only one that can simultaneously determine the amount of money supply for its domestic market and its exchange rate (OLIVERA, 1982).

The WB and the IMF have been powerless for their original functions. The IMS of Bretton Woods became the endogenous generation of world money from the credit of international banks and the creation of new financial assets in the continuous market, what is a consequence of the free international mobility of capital. The unlimited mobility of capital has the power to multiply the liquidity of the world system and to move it from one place to another of the world in seconds; in the face of this, there is no world monetary authority with functions equivalent to those of a central bank.

Sovereignty over the creation of international liquidity has been shifted to the managers of international financial capitals. This is at the basis of the current international financial crisis.

The global political - economic system established at the end of WW II is finished. A technological revolution transformed the global economic subsystem. The geopolitical reality has changed also.

But it has not been established yet an agreement on a new global statu quo, equivalent to the Yalta Conference. In fact, we can see the clear contradiction between the G7/G8 and the Security Council of the UN; in the same way, we can see the need for new institutions (wider than the G8) in the prominence

12 Translated by myself from the quoted Spanish version. 
acquired by the G20, which besides has been extended to some "guests countries".

Neither it has there been any new world conference that had taken control of the financial crisis in order to form a new IMS by establishing arrangements for a new global financial order, as it was done at Bretton Woods. The dollar is no longer the key currency of the IMS, but the dollar was not replaced by the euro (FIRMENICH, 1999) and besides some skeptics doubt today the survival of the euro. The Governor Zhou of the People's Bank of China argued that financial crisis is consequence of an inherent vulnerability of IMS because of the double roll of dollar as a national and global currency, such as the "Triffing dilemma" had raised (ZHOU, 2009). The IMF and the WB were not designed at Bretton Woods as monetary authorities for issuing a global currency, much less as the global lender of last resort. In addition, both institutions were completely ineffective in the failure of the system created at Bretton Woods. Finally, given the poor performance of the policies stemming from the Washington Consensus many people distrusts this institutions as regulatory institutions for a sustainable globalization.

While there has been a significant change from the General Agreement on Tariffs and Trade to the World Trade Organization (what has expanded globalization of markets for goods and services), the Doha Round is stalled. The formation of new regional - continental common markets are far from a finished process. The most developed model, which is the EU, has run aground in the failure of the treaty so - called European Constitution; now finds itself in a crisis which questions the very credibility of the euro and the BREXIT raises fears that other countries will leave the EU.

We are not facing a national crisis nor to many national crisis coinciding in time by random circumstances. Moreover, we can not simply consider that we are facing an "economic crisis", thinking that the economy is a self - sufficient reality. We are facing a global systemic crisis.

The solution can not be a national policy nor many simultaneous matching policies. Therefore, systemic solutions can not be a sum of national neo Keynesian policies, because that would just be a summation of partial solutions, none of which attacks the problem of the system as a whole.

The crisis affects the systemic order of globalization, and highlights the failure of the dogma that markets (in this case, global markets) optimally regulate themselves. The crisis highlights the absence of global political institutions which regulate global markets, what is particularly severe in the dysfunctionality of the institutional organization of international monetary and banking system.

The crisis highlights the end of energy - industrial model of the postwar period, but the supremacy of the new technologies arises not only from its economic advantages, but requires political decisions to end institutional 
supremacy of metalworking-petroleum economic interests, what so far has not happened.

The current global crisis demonstrates a dysfunction between the international economic subsystem and the international political subsystem.

In this case we can see evidence of a dysfunction between a long - term technology cycle that has exhausted its ability to expand but still retains its institutional power (ie: the cycle defined by the tandem automobile - petroleum) and a new technological cycle with the new ICT which are the infrastructure's basis for today's globalization, but this new cycle has not generated still the global institutions needed to manage it.

\section{A WRONG SOLUTION: OLD RECIPES AND NATIONAL POLICIES FOR A GLOBAL SYSTEMIC PROBLEM}

As we yet said, after national expansive policies, in 2009 the G20 agreed a multilateral pseudo - keynesian policy with an international agreement about simultaneous billionaires national fiscal stimulus and an expansive monetary policy.

A shy circumstantial economic revival was generated by the pseudo Keynesian policies, in 2008 / 2009, which was misinterpreted as overcoming structural crisis. But it was predictable the return of underlying symptoms of the crisis. Furthermore, there was a true probability about its extension for many years, if structural solutions were not taken, according the points of view of leading economists at the annual meeting of the American Economic Association (NICOLACI DA COSTA, 2010).

The misconception about the international crisis which enlightened the proposed solutions by the G20 in London is the logical cause of the failure of the measures taken with the aim of overcoming the crisis. Moreover, as it was experienced in the '30s and during the New Deal, there was a foreseeable likelihood that the extraordinary tax incentives, as well as bail out of the banks, give the paradoxical result of a weak cyclical recovery coupled with a shortage of credit as a result of an accumulation of reserves in commercial banks (LEE, 1955) $)^{13}$.

As we said also, in 2010, because of recurrence of the crisis on the stock markets and the public debt crisis in the EU's countries, EU returned to fiscal

${ }^{13}$ In Cap. XXI, § “La política monetaria y fiscal de 1933 a 1940”, (edition in Spanish, pp. 485-490), Lee says that the accumulation of excess reserves in the United States was driven, among other things, by the flight of the gold reserve of Europe after that "markets discounted" in advance the outcome of the crisis in World War II that would devastate Europe. Everything indicates that the EU crisis, which puts into question the survival of the euro as a common currency, would have generated a similar effect in 2012. 
adjustment.

The EU imposed drastic and urgent fiscal adjustments because of the default risk as consequence of the banking crisis (MARTÍN DE VIDALES CARRASCO, 2010), coupled with measures of "labor flexibility", both designed to "calm the markets". It should be recalled that in the context of financial globalization without a public global monetary authority, what prevents financing the fiscal deficit by issuing government debt in return for domestic money creation is the unrestricted capital's international mobility, because public debt becomes public extenal debt with default risk.

Can anyone imagine an economic recovery in a closed economy following a monetary policy that maximizes cash benefits of the monetary authority, which must regulate liquidity? Obviously it would be absurd for a Central Bank maximizes its monetary benefits, because it would imply the collapse of the real economy. What outcome can be expected on overcoming the global economic crisis if the monetary authority, which should regulate the international liquidity policy, are private banks, which seek to maximize their own short - term monetary benefits?

The invention of public central banks as monetary authorities for stabilizing the economy has been done under a premise: the money - issuing bank should "lose money" and no make money! The fiduciary debt - money is a liability of the bank that created it. So monetary authorities are public banks that are continually giving more money to agents of the real economy. But for private banks, ie the makers of credit money in neoliberal globalization, money is an asset and profit maximization implies continually take more and more money from the agents of the real economy through an exponential growth of its debts.

While the EU was implementing fiscal adjustment policies, US re - injected hundreds of billions of dollars, which feeds the devaluation of the dollar against all other currencies. The temptation of the policy of "beggar thy neighbor" through competitive devaluations, emerges as a reality that has been the focus of discussions at the V Seoul G20 Summit in November 2010, without meeting any specific solutions, and the final declaration was limited to a recitation of good intentions (G20, 2010).

Keynesian macroeconomic policies, designed for a context of closed national economies and monetary sovereignty of the nation - state, fail when one wants to manage the effective demand in the context of open economies, of globalization with the money power in the hands of international mobility of financial capital.

Neoliberal policies that seek to manage aggregate supply through structural reforms, fail because global markets are very, very far from perfectly competitive markets and because no market can be regulated optimally in the absence of political institutions. 


\section{THE SERIOUS RISK FOR THE GLOBAL PEACE OF NOT UNDERSTANDING THE SYSTEMIC NATURE OF THE GLOBAL CRISIS}

If we are unaware that we are in a new Kondratieff cycle, we can not see that we are ignoring certain regularities observed historically. Therefore, we would not expect a rational policy management, aware of the change process, to guide the overall sustainability of the new cycle's upward long wave, which has already lived more than two third parts of his probable existence. This means that it would be logical to expect a repetition, under peculiar forms, of those regular features of the long term cycles observed in the past.

The regularities observed in previous cycles include the two world wars of the twentieth century, as catastrophic disputes about the geopolitical hegemony and in order to financial, technological and markets control during the upward long wave of each cycle.

If the pseudo - Keynesian macroeconomic policy doesn't reactivate the global economy and neoliberal policies even less, what kind of solution could be seen as the right way by the people responsible for management of global political economic system?

This raises the very serious risk of a return to the literal interpretation of the ironies of Keynes:

"Pyramid-building, earthquakes, even wars may serve to increase wealth, if education of our statesmen on the principles of the classical economics stands in the way of anything better". (KEYNES, 1936, p. 116)

In fact, the world has been doing wars everytime over the present upward long wave of telematic Kondratieff cycle: the Balkans, Afghanistan, Iraq, Libya, Ukraine, Syria, Yemen,... Pope Francisco called it the Third World War by pieces.

If there is no concerted international management of a fully sustainable evolution of globalization, we could expect yet new dangerous worldwide tensions with a serious risk for the global peace.

The inability to manage the building of an institutional framework for a globalization fully sustainable could end reiterating past attempts to impose a new world order through a world war between the main powers. Of course, if one considers the extreme ecological fragility in which we live, as well as the brutal capacity of existing weapons of mass destruction, this would be "The Last World War".

A New International Order is a political construction. No determinism is to be expected, nothing inexorably will happen. What corresponds is to negotiate a globalization that must be fair, from the perspective of the people, and sustainable from an ecological point of view in terms of the survival of the human species. 


\section{CONCLUSIONS: REDESIGN OF MULTILATERAL INSTITUTIONS, TECHNOLOGICAL REVOLUTION AND REDEFINITION OF MACROECONOMIC POLICIES FOR SUSTAINABLE GLOBALIZATION}

It is a need to redefine efficient policies to the context of a fully sustainable globalization, which will not be the automatic result of "optimal markets" nor of the mechanical "development of the productive forces", but it will be the result of a conscious political decision on the design of a global institutional framework as well as the preeminence of new technologies, accompanied by a new focus on monetary and fiscal policies to manage the effective demand (FIRMENICH, 2004).

On one hand, we have to realize that the effective demand management can not be done from public spending as it was traditional, but it can be done, however, managing private consumption, generating efficiency gains. Moreover, the most disastrous way of managing effective demand from government spending is manage it by war.

It seems it have been reached the limit of "debt - money" model of monetary system, which requires, for the issuance of cash (as a liability of the Central Bank), the issue of public debt (as an asset on the books of the Central Bank). This model requires a growing public debt without limit, since public debt issued today requires to issue more debt in the future to pay the interest accrued; the model requires that debt continue to be growing and unpaid for ever, since if the state pays all of the bonds of public debt to Central Bank, the monetary base would be reduced to a minimum amount.

In addition, a comprehensive sustainability requires hasten the end of the hegemony of the technologies of "automotive Kondratieff" to promote, with global political decisions, the hegemony of the technologies of "telematic Kondratieff".

Finally, it is not possible postpone any longer the requirement to negotiate multilaterally the foundation of a new international order, fully sustainable. This includes a new international monetary system.

The model for a fully sustainable development of a global political - economic system must enroll in the requirements, constraints and opportunities of the new long - term cycle, the "telematic Kondratieff" cycle. This means that any development model, national or regional / continental, is impossible if there is no sustainable globalization. This fact is also true for the superpowers.

If the global order, as a result of the integration, acquired the nature of a political - economic system, then any national or regional social order became a subsystem, unable to achieve an auto - regulated equilibrium. Therefore, a fully sustainable global system can not be built from autonomous national policies but 
requires building global institutions capable to manage it under the premise of multilateral peace negotiations.

\section{BIBLIOGRAPHIC REFERENCES}

AGLIETTA, M. (1987). El fin de las divisas clave - ensayo sobre la moneda internacional. México: Siglo XXI

BERTALANFFY, L. VON (1968). General System Theory. Foundations, Development, Applications. Revised edition. New York: 2001, George Brazilier, Inc.

EL UNIVERSO (2008). "Salvataje Europeo Sí Logró Tranquilizar a Bolsas Mundiales". October 14. Disponible en: http://www.eluniverso.com/2008/10/14/0001/14/ CA9A3D171FD24D1592B8FD5903C9F29D.html . [Último acceso: 08 de diciembre de 2013].

FIRMENICH, M. E. (1999). "El euro y el Sistema Monetario Internacional". Paper exposed at the I Encuentro Internacional de Economistas sobre Globalización y Problemas del Desarrollo. La Habana, Cuba, 18 al 22 de enero de 1999.

FIRMENICH, M. E. (2004). EUTOPÍA - Una Propuesta Alternativa Al Modelo Neoliberal. Buenos Aires, Ediciones Colihue, $1^{\mathrm{a}} \mathrm{Ed}$, Cap. 8. "Política económica anticíclica administrando la demanda de consumo privado". Cap. 9. "Nueva política para administrar la oferta monetaria". Cap. 10. "Transparencia monetaria y recaudación fiscal", (pp. 191 a 211).

FIRMENICH, M. E. (2015). Teoría de los sistemas político - económicos. Argentina: Neuquén, EDUCO - Editorial de la Universidad Nacional del Comahue.

G20 (2009). London on April 2, 2009, "Global Plan For Recovery And Reform": The Communiqué From The London Summit. Disponible en: http://www.londonsummit. gov.uk/ . [Último acceso: 08 de diciembre de 2013].

G20 (2010). The final declaration of the $V$ Summit of the meeting in Seoul in November 2010. Disponible en: http://media.seoulsummit.kr/contents/dlobo/E1._Seoul_ Summit_Leaders_Declaration.pdf [Último acceso: 08 de diciembre de 2013].

GIULIANO, G. (2008): Tecnología, Desarrollo Y Democracia: Hacia Otra Artificialidad Posible. Sci. stud., São Paulo, v. 6, n. 3, September. Disponible en: http://www.scielo.br/scielo.php?script=sci_arttext\&pid=S1678-31662008000300006 \&lng=es\&nrm=iso . [Accessed on June 19. 2010. doi: 10.1590/S167831662008000300006].

HARRIS, M. (1991). Introducción a la Antropología General. $3^{a}$ Ed. revisada y ampliada. Madrid: Alianza.

HELBLING, T. \& TERRONE, M. (2003). With research assistance of CONOVER, E.: "When Bubbles Burst". World Economic Outlook, IMF, April 2003, Chapter II.

HERRING, R. \& WACHTER, S. (2002). "Bubbles in Real Estate Markets". Zell / Lurie Real Estate Cente, Working Paper \#402, March 2002. Prepared for the Federal Reserve Bank of Chicago and World Bank Group's Conference on "Asset Price Bubbles: Implications for Monetary, Regulatory, and International Policies" in Chicago on April 22-24, 2002. Disponible en: http://housing-bubble.com/PDFGate/bubbles.html . [Último acceso: 08 de diciembre de 2013]. 
HOFF, K. y STIGLITZ, J. E., (2001). "Modern Economic Theory and Development". In Frontiers of Development Economics - The future in perspective, Edited by MEIER G. M. and STIGLITZ, J. R., Copublication of The World Bank and Oxford University Press

IZQUIERDO, M. P. (ed.) (1979). Kondratieff, Trotsky, Mandel, Garvy, Day - Los Ciclos Económicos Largos ¿una Explicación De La Crisis?. Madrid: Akal editor. It includes Spanish translation of the Kondratieff (1925) full text.

KEYNES, J. M. (1936). The General Theory of Employment, Interest and Money. New Delhi: ATLANTIC, 2008.

KONDRATIEFF, N. D. (1925). "The Long Economic Cycles", first published in Russian in Voprosy Conjunktury, Volume 1. The German translation was published in Archiv für und Sozialwissenschaft Sozialpolitik, vol. LVI, 1926. It is published in English in The Review of Economic Statistics, Volume XVIII, November 1935, but in summary and without the statistical tables.

LEE, M. W. (1955). Economic Fluctuations: Growth and Stability, Illinois, Richard D. Irwin, Inc.; Homewood. Edited in Spanish by EUDEBA, Buenos Aires, 1967, translated from the 2nd edition published in 1959.

LUTTWAK, E. (1996). "Un Mundo Sin Empleos?". In Archivos del Presente, Buenos Aires, Year 2 / Issue 6, October - December.

MARTÍN DE VIDALES CARRASCO, I. (2010). "EI Impacto De La Crisis Económica Y Financiera Sobre El Sistema Bancario De Grecia". Boletín Económico de Información Comercial Española, № 3001, pp. 33-46.

Mc CLELLAND, C. A., (1958). "Systems and history in international relations - Some perspectives for empirical research and theory". General Systems, 3

NICOLACI DA COSTA, P. (2010). "Us Financial Crisis Far From Over, Economists Say". REUTERS, January 4. Disponible en: http://in.reuters.com/article/idINN042379122 0100104. [Último acceso: 08 de diciembre de 2013].

NORTH, D. C. (1981). Structure and Change in Economic History. New York - London: WW Norton \&Company,

OLIVERA, J. H. (1982). "On passive money, exchange rates and monetary leadership". Kredit und Kapital, vol. 15, № 2.

PIRES MANSO, J. R. \& BASHIRI BEHMIRI, N. (2013). "Renewable Energy and Sustainable Development". Estudios de Economía Aplicada, 31(1), pp. 7-34.

PRELOOKER, M. (1996). La Economía del Desastre - Un Sistema Que Se Sostiene Por Inercia. Buenos Aires: Grupo Editor del Encuentro

SCHUMPETER, J. (1939). Business Cycles. New York: McGraw Hill Books.

SRAFFA, P. (1960). Production Of Commodities By Means Of Commodities. The Syndics of the Cambridge University Press

TAYLOR, P. J. (1985). Political Geography: World-Economy, Nation-State and Locality, London, Longman, 1st ed., 1985, 3rd ed. Revised 1993; 1st ed. in Spanish, Trama Editorial, Madrid, December 1994

THE NEW YORK TIMES (2008). "How This Bear Market Compares". October 11. Disponible en: http://www.nytimes.com/interactive/2008/10/11/business/20081011_ BEAR_MARKETS.html [Último acceso: 08 de diciembre de 2013].

THE WORLD BANK (2012). "Turn Down the Heat: Why a $4^{\circ} \mathrm{C}$ Warmer World Must Be Avoided", A Report for the World Bank by the Potsdam Institute for Climate Impact Research and Climate Analytics, November 2012. Disponible en: 
http://www.bancomundial.org/es/news/2012/11/18/new-report-examines-risks-ofdegree-hotter-world-by-end-of-century . [último acceso: 08 de diciembre de 2013].

VOLTES BOU, P. (1980). La Teoría General de Sistemas y la Historia. Universidad de Barcelona, Facultad de ciencias Económicas y Empresariales, Departamento de Historia Económica.

WILLIAMSON, J. (ed.) (1990). "Latin American Adjustment: How Much Has Happened?". Washington, Institute for International Economics.

WORLD METEOROLOGICAL ORGANIZATION (2012). GREENHOUSE GAS BULLETIN.

Disponible en: http://www.wmo.int/pages/mediacentre/press_releases/ pr_965_en.html . [Último acceso: 08 de diciembre de 2013].

ZHOU, X. (2009). "Reform of the International Monetary System". website of the People's Bank of China, 23 March 2009. Disponible en: Bank for International Settlements http://www.bis.org/review/r090402c.pdf . [Último acceso: 08 de diciembre de 2013]. 